\title{
EJSBS
}

The European Journal of Social \&

Behavioural Science

ISSN: 2301-2218 (ONUNE)
OPEN ACCESS

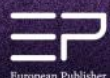

The European Journal of Social and Behavioural Sciences

EJSBS Volume XXX, Issue II (eISSN: 2301-2218)

\section{THE IMPLEMENTATION OF MASSIVE OPEN ONLINE COURSES INTO EDUCATIONAL PROCESSES AT RUSSIAN UNIVERSITIES}

\author{
Tatiana Nikolaevna Bokova ${ }^{\mathrm{a}}$, Olga Aleksandrovna Kabanova ${ }^{\mathrm{b} *}$ \\ ${ }^{a}$ Moscow City University, 4 Vtoroy Selskohoziajstvenny proezd, Moscow, 129226, Russia \\ ${ }^{b}$ Moscow City University, 4 Vtoroy Selskohoziajstvenny proezd, Moscow, 129226, Russia
}

\begin{abstract}
Interest in massive open online courses (MOOCs) as a new resource for distance learning is due to the rapid development of information and communication technologies within the framework of education. The 2000s precipitated the development of e-learning in the direction of open learning opportunities which resulted in the phenomenon known as MOOCs. MOOCs are now a widespread and accepted means of higher education which implies interactive online learning. Therefore, it is relevant to define the most appropriate form of MOOC integration, to study the contemporary experiences of MOOC implementation into higher education along with analysing the experience of using online courses within the context of face-to-face classes. This study observes the development of MOOCs by using comparative analysis and literature examination to reveal some accepted blended learning models for higher education. This paper also attempts to show possible challenges and outcomes of MOOC integration into a face-to-face class. The findings are dedicated to effective use of massive open online courses in universities in Russia.
\end{abstract}

Keywords: MOOC, blended learning, face-to-face learning, distance learning, e-learning; higher education

C 2021 Published by European Publisher. www.europeanpublisher.com

${ }^{*}$ Corresponding author.

E-mail address: bokovatn@mgpu.ru; kabanovaoa@mgpu.ru

doi: $10.15405 /$ ejsbs.291

This work is licensed under a Creative Commons Attribution-NonCommercial-NoDerivatives 4.0 International License. 
https://doi.org/10.15405/ejsbs.291

eISSN: 2301-2218 / Corresponding Author: Olga Aleksandrovna Kabanova

Selection \& Peer-review under responsibility of the Editors

\section{Introduction}

New challenges have emerged with the digitalisation of higher education and researchers' attention is now riveted on the various ways to implement informational and communication technologies (ICT) into universities' traditional practices of designing teaching materials and teaching practices in general. Some scholars admit that several years ago, many educators doubted that distance education would be successful. Nevertheless, it appears that, despite technical difficulties and extensive maintenance costs, as well as the preparation of teaching materials and revamping of teaching practices, today, distance learning by means of online tools for education is obligatory in most universities (Pluzhnikova et al., 2018).

ICT has been supporting educators from the end of the 20th century. These technologies have become steadily more advanced, offering more proficient options for placing study materials online (websites), exchanging different files (email), managing classes and courses (course management system (CML)), improving different skills in the language laboratory, participating in intercultural communication online (social networks, telecommunications applications) and finally Internet platforms which allow for the design of independent open courses for large audiences (MOOCs - massive open online courses). The term massive open online course was coined in 2008 by Dave Cormier. Later, Stanford University professors allowed access to their courses with over 100,000 people enrolling in the courses. After that, the advancement of MOOCs as providers of online courses on a global scale took off in 2011 and the first platforms (Udacity, Coursera, EdX, FutureLearn) appeared, making MOOCs a global phenomenon in higher education. One of the main benefits of MOOCs is its accessibility and openness which can gather a diverse group of learners to participate in the course regardless of their social or cultural background (Gütl et al., 2014) as well as different levels of education and income.

Every year the number of the MOOCs being offered is rapidly growing. Tambovkina (2017) highlighted that using ICT in education is unavoidable for various reasons among which the reduction of face-to-face teaching hours is an important one. Some scholars (Berdichevsky et al., 2020, p.115) believe that online education alone is not effective enough and therefore, support blended learning, an approach combining online education with the traditional face-to-face learning at the university. Furthermore, blended learning can be an effective way to familiarise students with online learning peculiarities enabling them to utilise online courses effectively (Fidalgo et al., 2020). However, it is also relevant to note that educational innovation embodied in new technologies is mainly considered to be a tool for developing learners' creative thinking, innovative skills and individualisation while the 
https://doi.org/10.15405/ejsbs.291

eISSN: 2301-2218 / Corresponding Author: Olga Aleksandrovna Kabanova

Selection \& Peer-review under responsibility of the Editors

educator and his/her professional autonomy contributes to an effective educative process (Gavrilyuk et al., 2019).

\section{Problem Statement}

There is a scarcity of studies from educators themselves on an appropriate and effective model to utilise MOOCs within blended learning. The current paper aims to fill that gap by focusing on MOOC integration outcomes, challenges and the possible ways of overcoming them.

\section{Research Questions}

The study focuses providing answers to the following questions:

3.1 What model of blended learning is the most complementary for MOOC implementation at the university?

3.2 How can MOOCs be implemented into face-to-face courses at a university within a blended learning model in order to optimise classroom hours?

\section{Purpose of the Study}

Current realignment of teaching and learning at universities involve not only designing materials for MOOCs but also implementing these relatively new means of teaching and learning into the face-to-face environment. The studies dedicated to the above-mentioned question highlight that MOOCs are usually implemented into traditional classrooms using hybrid or blended models as a sustainable process. Nevertheless, some scholars (Israel, 2015; Wang et al., 2019) agree that there is still a paucity of data concerning universities' experiences in MOOC implementation. Hence, the current paper aims to analyse some of these experiences and present the findings of using a MOOC within a blended learning model at a university as a supplementary educational tool.

\section{Research Methods}

\subsection{Sample}

A questionnaire was implemented among the cohort (academic year 2019-2020) taking "Practice of intercultural communication" subject as part of their professional training in the field of Pedagogical Education at Moscow City Pedagogical University. The cohort comprised 25 third-year preservice foreign language teacher trainees. The sampling procedure was 
https://doi.org/10.15405/ejsbs.291

eISSN: 2301-2218 / Corresponding Author: Olga Aleksandrovna Kabanova

Selection \& Peer-review under responsibility of the Editors

purposeful in nature as the researchers wished to investigate the perceptions of the whole cohort to the implementation of the MOOC into the course.

\subsection{Research instrument}

In the current study, the scholarly literature was analysed in order to highlight relatively widespread blended learning models and elicit MOOC implementation experiences outcomes along with possible challenges. The research was experimental in nature where the responses of the study sample were elicited to the implementation of a MOOC within a blended learning format in a teaching a particular subject in a Russian university.

The researcher designed questionnaire consisted of 4 sections and was conducted using Google forms. The first section focused on the general information about students including the university where they were studying, their major, the study year, their age and nationality, and reasons for studying English. All the sampled students were studying at the Moscow City Pedagogical University and the age breakdown ranged from 19 to 22 . The question concerning students' gender was not applicable to the cohort since there was only one male student in the cohort. The second section based on scaled responses of 1 to 5 , the students had to rate the relevance of the topics within the course in terms of their effectiveness for intercultural communication. In the third section also based on scale responses, the students had to rate different activities which were a part of the course. This part of the questionnaire was necessary to identify the most efficient ways of interacting with students within the course. The last section was mainly aimed at investigating the overall impact of the one-year course on students' readiness for intercultural communication and the relevant feedback to enhance the development of intercultural communicative competence by making blended learning even more efficient for the future students. Therefore, the items were developed to answer the research questions.

In this paper, only 3 data units are discussed since they are relevant for the current research which is focused on the results of MOOC implementation within the context of a face-to-face class. The remaining questionnaire items representing the students' feedback on the content regarding relevant topics and activities for developing students' intercultural communicative competence were auxiliary in nature to the main aim of this study and were used to deepen the researchers', who were also the instructors of the cohort, understanding about the application of the blended learning model for this subject. 
https://doi.org/10.15405/ejsbs.291

eISSN: 2301-2218 / Corresponding Author: Olga Aleksandrovna Kabanova

Selection \& Peer-review under responsibility of the Editors

\section{Findings and Discussion}

\subsection{Blended learning}

Clark (2003) and Bricault (2015) provide a classification of blended learning based on the integration of ICT into the educative process in universities. This categorisation includes web-enhanced learning implying the placement of the announcements and some content of the course online; blended learning implying $45 \%$ of the course to be held online; hybrid learning implying $45 \%$ to $80 \%$ of the course held online; and fully online learning implying more than $80 \%$ of the course being held online.

The blended learning classification based on the major components of the course suggests the following divisions:

- Face-to-Face Driver (predominantly traditional teaching using the Internet and distance learning tools only for auxiliary purposes which correlates with the 'webenhanced' model from the previous classification);

- Rotation (classroom rotation, laboratory rotation, 'Inverted classroom' or flipped class, individual rotation (Nagaeva, 2016, p. 62); this correlates with the 'blended' model from the previous classification);

- Flex (flexible model, individual educational path of students, work in small groups, implementation of group projects);

- Online Lab (laboratory work performed online with an actual presence of students in a class);

- Self-blend (an independent choice of courses for students to take online based on personal needs to supplement their knowledge and skills as they progress through a full-time course);

- Online Driver (self-education, the course is online, sessions with the course teacher are possible; correlates with the 'fully online' model from the previous classification) (Kravtsov et al., 2015, p.661).

When selecting the most effective model for the implementation of blended learning at the undergraduate level at a language university, we should take into consideration that in teaching foreign languages the face-to-face discussions of the studied online material have particular importance. Therefore, in this case, it is appropriate to use a model involving the interaction of students both face-to-face and online. Accordingly, from the above-mentioned division of blended learning models, the optimal one for a language university is a rotation model with the elements of an inverted class when students get acquainted with the course 
lectures online. The flexible model provides students with the opportunity of participating in group projects and communicating with their peers.

The choice of a rotational model with the use of additional components of blended learning is supported by the results of this study, in which an online course (MOOC) was used to supplement the content of face-to-face classes with lectures (knowledge component). It is important to emphasise that most of the students preferred the rotational model of blended learning (see Figure 1). At the same time, it should be noted that the most complementary MOOC for face-to-face learning is the one designed by an instructor who conducts the faceto-face classes and allots tasks based on the content of the online and traditional university courses. Thereby, the MOOC will contribute to the integrality of the discipline.

\section{What is the most effective way to use an onlinecourse in the face-to-face learning?}
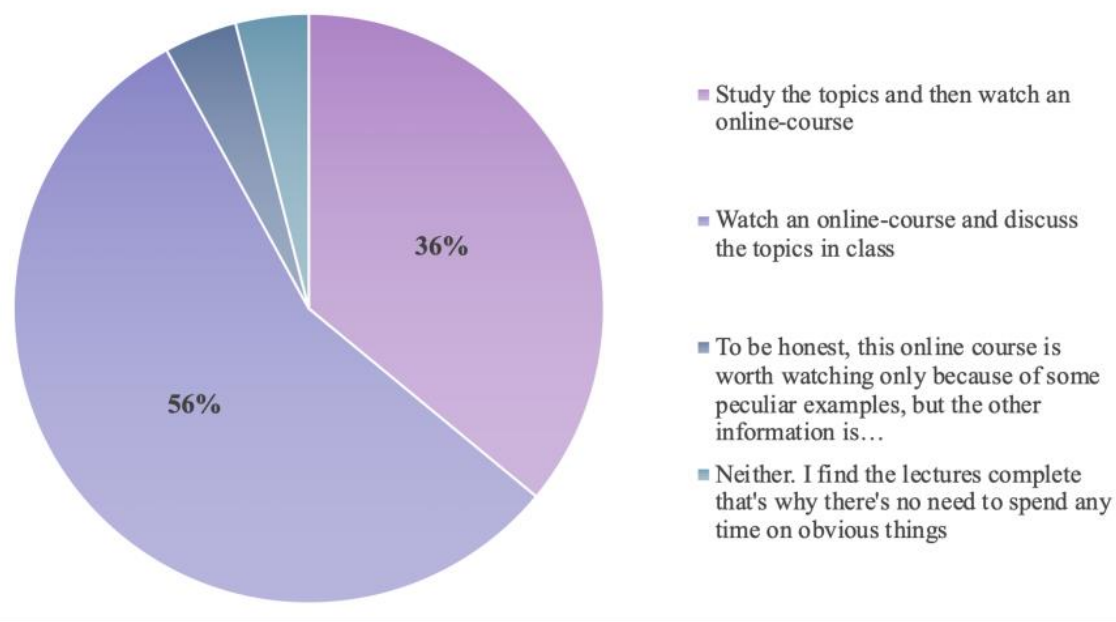

n Neither. I find the lectures complete that's why there's no need to spend any time on obvious things

Figure 1. The Preferable Model of Blended Learning for Third-year Students

There are two main formats for MOOC implementation: self-paced and tied to particular dates. The first format was widely used when MOOCs started developing. However, the data from Class Central (a search engine that reviews sites for free online MOOCs) reveals the following: only 19\% of MOOCs presented on the largest platforms (Coursera, FutureLearn, edX, Canvas Network, Independent) are self-paced today (Borshcheva et al., 2017, p.49). Other courses have the enrolment date and a certain schedule within the subject. Open Education, one of the most popular MOOC providers in Russia, is structured along the latter format. 
https://doi.org/10.15405/ejsbs.291

eISSN: 2301-2218 / Corresponding Author: Olga Aleksandrovna Kabanova

Selection \& Peer-review under responsibility of the Editors

\subsection{The possible challenges and outcomes of MOOC implementation}

The integration of an online course into a face-to-face learning context poses some challenges to face-to-face learning and teaching. Wang et al. (2019) conclude in their threeyear study of implementing MOOCs into university courses that typically several problems can be encountered. First of all, students tended to log in and not get acquainted with the lectures since it is difficult to check whether they are actually watching the lectures and study materials. Also, the tasks and tests in the online course might be completed with help of the Internet. Furthermore, controlling students' actual engagement with a MOOC is limited. It is also necessary to pay attention to the assessment within the online environment as assessment is an integral part of the learning process (Thambusamy \& Singh, 2021). Furthermore, instructors would prefer not to be additionally burdened in terms of workload by having to provide students with additional support while they study with help of the online courses where they require an instructor to answer their questions to get a deeper understanding of the study material. The other questions to solve are connected with the fact that grading systems within an online course and a face-to-face course may differ substantially; hence creating a need for the development of a grading system that integrates the online participation which would motivate students to participate in an online course. However, according to Kursun (2016) citing Billington and Fronmueller (2013) "a successful MOOC completion is not recognized as a formal credit by most universities" (p.76). This means that student participation in MOOCs recognized with "non-credit alternatives such as completion, attendance, or participation certificates" (Yousef et al., 2014 as cited in Kursun, 2016, p.76) may demotivate students from fully participating in the MOOC.

You's (2019) research on students' perception about learning using a MOOC showed that students usually tend to participate in a MOOC if they believe it would be beneficial in improving their academic results. Another study conducted by Israel (2015) has shown relatively positive tendencies of integrating MOOCs in traditional classrooms. The students' academic performance results while participating in the MOOC online course tended to be almost equal or slightly better compared to the results of the students who participated in a fully face-to-face learning process. This study noted that among the benefits resulting from the MOOCs usage at a university were improvement of students' critical thinking in terms of their ability to distinguish between opinions and augmentations and also their skills for providing proper analytical comments.

Some scholars agree on the ways of improving the MOOC itself and the online course integration experience, based on their findings for both students and instructors at universities. Aharony and Bar-Ilan's (2016) study highlighted that students also have different needs and 
https://doi.org/10.15405/ejsbs.291

eISSN: 2301-2218 / Corresponding Author: Olga Aleksandrovna Kabanova

Selection \& Peer-review under responsibility of the Editors

expectations which need to be considered while designing or implementing MOOCs into the teaching process. Wang et al. (2019) suggest that students are provided with an opportunity to amend the online course content within two first weeks to satisfy their contemporary academic needs. Moreover, the MOOC should contain video lectures not longer than 10 or 20 minutes in duration and include more interactive functions. Blended learning can also be enhanced by encouraging peer learning, providing both online and offline instructor support, and releasing video lectures and other materials gradually instead of allowing access to all these materials at once. In order to enhance students' outcomes through MOOC implementation in traditional higher education courses, redesigning face-to-face courses is mandatory (Griffiths et al., 2014). Other scholars also emphasise the importance of instructors' facilitation and encouraging students to participate in discussions within the course. As for the MOOC itself, they believe videos with instructions for assignments might be quite useful for students (Yang $\& \mathrm{Su}, 2017)$.

Some of the above-mentioned methods of overcoming possible problems with MOOC integration within the traditional learning process at universities are viable. Using a MOOC within blended learning to improve students' results and optimising classroom hours implies that the online component is instructor designed. Moreover, the assessment system too, would require realignment to stimulate students' motivation for participating in the online course in terms of academic performance. The experience of MOOC implementation in a traditional university course is discussed in detail in the following section.

\subsection{Experience of implementing MOOC into face-to-face teaching}

The cohort of the academic year 2019-2020 taking the subject "The Practice of Intercultural Communication" at Moscow City Pedagogical University participated in this study where a MOOC was integrated into their face-to-face class. The MOOC chosen for this course was placed on the Open Education platform and titled "Language, Culture and Intercultural Communication". This online course was designed by Moscow State University professor S.G. Ter-Minasova and met the requirements of the contemporary foreign language education at the university aimed at developing students' intercultural communicative competency.

The integration of the MOOC involved watching informative lectures on the language and culture related topics in order to facilitate students' understanding; hence, developing their ability to practise effective intercultural communication in the future. In addition to the MOOC themes for discussion, the students were offered a variety of relevant content which included techniques for overcoming stereotypes, recognizing stages of culture shock, building 
https://doi.org/10.15405/ejsbs.291

eISSN: 2301-2218 / Corresponding Author: Olga Aleksandrovna Kabanova

Selection \& Peer-review under responsibility of the Editors

connections between language and thinking, debating on the World Englishes issue, discussing globalisation and its influence as well as other intercultural matters which might cause misunderstanding.

The MOOC had a particular structure consisting of the video lectures separated by brief quizzes to check if students managed to understand and remember the aspect covered in the lecture. Then, at the end of the topic, students had to complete a longer test, followed by a creative task - a peer assessed essay - after certain portions of the MOOC were covered. Since the online course is open and accessible to a large audience and also uses Russian and English as the mediums of instruction, students were offered an alternative manner of completing the essays. The medium of instruction of the face-to-face course was English only and therefore, it was expected that the essay would be written in this language. The informative component of the students' essays was more in depth and wider in the second semester due to the integration of the online course as in comparison with the first semester as the students were receiving and analysing the materials under study not only in class and through some additional recourses, but also by watching the MOOC which made the revision process more effective.

The peer assessment was also held in the face-to-face class. The written essays were equally distributed among the students and it is important to highlight that the peer assessment task was not signed and remained anonymous. Nevertheless, the third-year students tended to recognise each other's writing style and the objectiveness of their grades and comments were quite questionable on account of the biased esteem in favour of their peers. Therefore, this peer assessment could not be a part of the grading system within the course and was mainly used as peer feedback in the first semester of the 2019-2020 academic year. The gained experience was used in the following semester to make the peer assessment a more relevant experience for students so that they could get some feedback both from their instructor and peers in order to improve their writing on the topics within the course. Consequently, in the following semester, students were allowed to evaluate their peers' essays (which were anonymous). This time, students were more objective, providing a more critical assessment and objective feedback along with the recommendations to improve the work. Table 1 shows the rubric used for the peer assessment task.

Table 1. Criteria for the peer assessment

\begin{tabular}{llc}
\hline & 1. Word Count & \\
\hline Unsatisfactory & $200-300$ & 2 \\
Satisfactory & $300-400$ & 3 \\
Good & $400-500$ & 4 \\
Excellent & 500 and more & 5 \\
\hline
\end{tabular}




\begin{tabular}{|c|c|c|}
\hline & 2. Structure & \\
\hline Unsatisfactory & There is no structure & 0 \\
\hline \multirow[t]{3}{*}{ Satisfactory } & Introduction & 2 \\
\hline & Main body & \\
\hline & - Conclusion & \\
\hline \multirow[t]{5}{*}{ Good } & Introduction & 4 \\
\hline & Main body & \\
\hline & 1. showing the deep understanding of the topic; & \\
\hline & 2. examples & \\
\hline & - Conclusion & \\
\hline \multirow[t]{7}{*}{ Excellent } & Introduction & 5 \\
\hline & Main body & \\
\hline & 1. showing the deep understanding of the topic; & \\
\hline & 2. using: active vocabulary; & \\
\hline & 3. examples & \\
\hline & - Conclusion & \\
\hline & 3. Relevance to the topic & \\
\hline Unsatisfactory & $\begin{array}{l}\text { It is clear that the author is not acquainted with the topic and } \\
\text { the under study materials }\end{array}$ & 0 \\
\hline Satisfactory & $\begin{array}{l}\text { It is hard to tell if the author understands the topic and the } \\
\text { under study materials }\end{array}$ & 2 \\
\hline Good & $\begin{array}{l}\text { The author is acquainted with the topic and the under study } \\
\text { materials }\end{array}$ & 4 \\
\hline \multirow[t]{2}{*}{ Excellent } & $\begin{array}{l}\text { The author fully understands the topic. It is clear that he/she } \\
\text { digested the under study materials and has his/her own } \\
\text { opinion }\end{array}$ & 5 \\
\hline & 4. Examples & \\
\hline Unsatisfactory & There are no examples & 0 \\
\hline Satisfactory & There is only one example & 3 \\
\hline Good & $\begin{array}{l}\text { There are only examples from the materials under study (Ted } \\
\text { talk, the film, the individually read articles) or/and from the } \\
\text { author's own experience }\end{array}$ & 4 \\
\hline \multirow[t]{2}{*}{ Excellent } & $\begin{array}{l}\text { The author provides the reader with examples from his/her } \\
\text { own experience, mass media, literature etc. and also from the } \\
\text { materials under study (Ted talk, the film, the individually read } \\
\text { articles) }\end{array}$ & 5 \\
\hline & 5. Decide whether the essay inspires a further discussion & \\
\hline Unsatisfactory & $\begin{array}{l}\text { There is no reasoning in the essay and it is hard to understand } \\
\text { the author's idea }\end{array}$ & 0 \\
\hline Satisfactory & $\begin{array}{l}\text { The reasoning repeats the under study materials and doesn't } \\
\text { inspire a further discussion }\end{array}$ & 2 \\
\hline Good & $\begin{array}{l}\text { The reasoning repeats the under study materials but inspires a } \\
\text { further discussion }\end{array}$ & 4 \\
\hline Excellent & $\begin{array}{l}\text { The author's reasoning is interesting and creative. The essay } \\
\text { inspires a further discussion }\end{array}$ & 5 \\
\hline
\end{tabular}


As for the tests, students could complete them within the MOOC. However, after each new lecture, they had another test on the topic with a particular time limit in class to check students' actual knowledge of the subject. The tests were prepared in Microsoft Forms with start and end times preset. Hence, the problem of poor control over MOOC assessment was solved though it required the instructor to spend extra time on the test design as formatting the test content and the assessment in Microsoft Forms was quite time consuming.

All in all, the findings of this study show that students found the MOOC quite useful for their studies. They paid particular attention to the examples used within lectures on the peculiarities of intercultural communication. This knowledge would help students in the future career of foreign language teachers and also in building interpersonal or professional relationships with people from different countries. The following charts show a positive dynamic in students' knowledge and readiness for intercultural communication (see Figures 2 and 3).

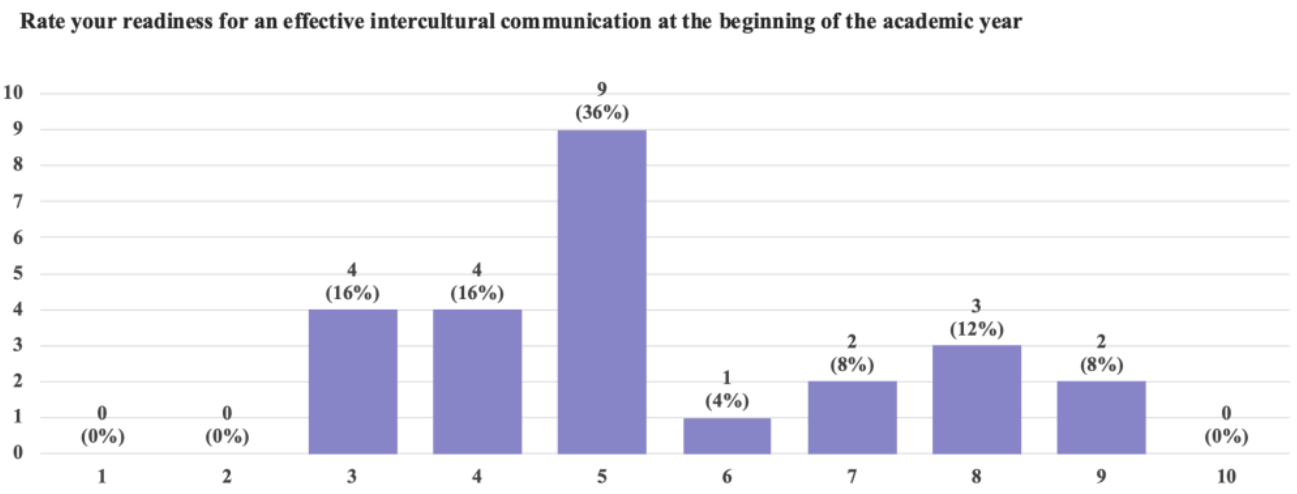

Figure 2. Readiness for intercultural communication before the course

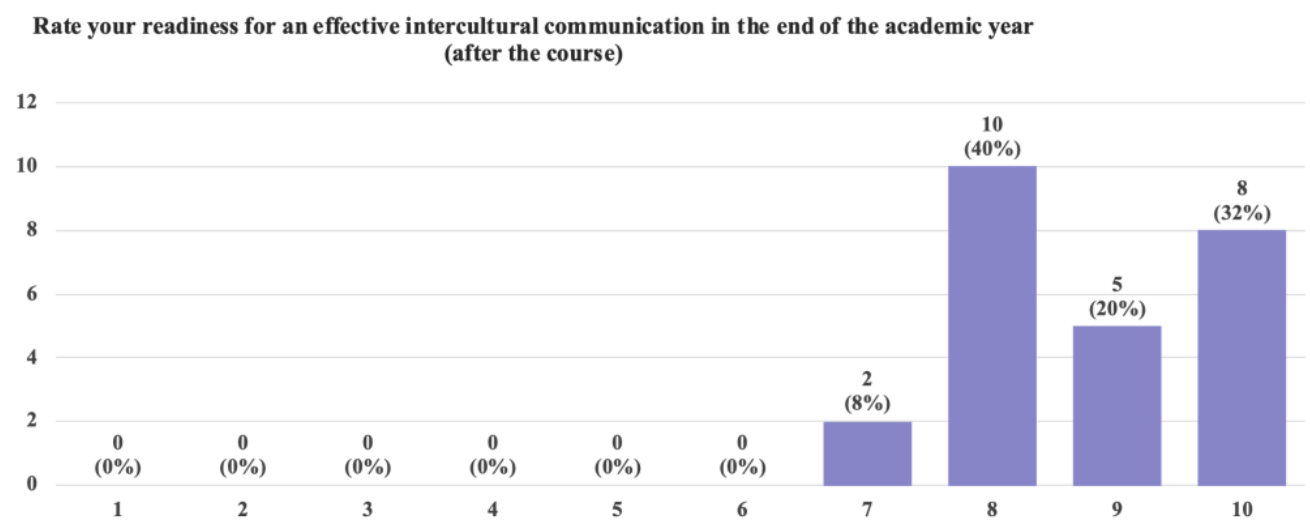

Figure 3. Readiness for intercultural communication after the course 
https://doi.org/10.15405/ejsbs.291

eISSN: 2301-2218 / Corresponding Author: Olga Aleksandrovna Kabanova

Selection \& Peer-review under responsibility of the Editors

\section{Conclusion and Implications}

Within the context of this study, the implementation of MOOCs within the blended learning format in higher education allowed instructors to cover the topics of the course extensively and systematically. The face-to-face teaching hours were utilised more effectively due to the integration of online lectures and tasks like a peer assessed essay being used from the online course component. Therefore, the face-to-face class time was optimized as it could be devoted to the discussion of the problematic issues, performing practical tasks and enhancing students' cognitive activity in the formation and development of the key skills within the course. The accessibility of the online course to a large audience provides students the opportunity to participate in contemporary intercultural communication with people from different countries which facilitates a deep understanding of the course materials. In conclusion, this study found that the implementation of the MOOC into the educative process at the university provided the bachelor degree students with a wider range of learning opportunities and improved students' academic achievements.

The findings of this study will be useful for other instructors who are keen in incorporating MOOCs into their coursework. Instructor designed MOOCs would be ideal as the instructors would know the capabilities and needs of the students which they can incorporate into the design and implementation of the course.

\section{Acknowledgements}

The author(s) declare that there is no conflict of interest.

\section{References}

Aharony, N., \& Bar-Ilan, J. (2016). Students' perceptions on MOOCs: An exploratory study. Interdisciplinary Journal of e-Skills and Life Long Learning, 12, 145-162.

Berdichevsky, A. L., Giniatullin, I. A., \& Tareva, E. G. (2020). Metodika mezhkul'turnogo inoyazychnogo obrazovaniya $v$ vuze: uchebnoe posobie (2 izdanie) [Methodology of intercultural foreign language education at the university: study guide (2nd ed.)]. FLINTA.

Borshcheva, V. V., Kashparova, V. S., \& Sinitsyn, V. Y. (2017). Ispol'zovanie massovyh otkrytyh onlajn-kursov v obuchenii anglijskomu yazyku studentov nelingvisticheskih napravlenij podgotovki. [The use of massive open online courses in teaching English to students of non-linguistic areas of training. Pedagogy and psychology of education], $1,45-53$.

Bricault, D. (2015). Blended Learning in English Language Teaching: Course Design and Implementation. In B. Tomlinson, \& C. Whittaker (Eds.), TESOL Quarterly, 49(1), 210-212. https://doi.org/10.1002/tesq.215

Clark, D. (2003). Blended Learning: An Epic White Paper. https://ru.scribd.com/document/84278 560/Clark-D-Blended-Learning 
Fidalgo, P., Thormann, J., Kulyk, O., \& Lencastre, J. (2020). Students' perceptions on distance education: A multinational study. International Journal of Educational Technology in Higher Education, 17(1), 1-18. https://doi.org/10.1186/s41239-020-00194-2

Gavrilyuk, O., Tareva, E., \& Lakhno, A. (2019). Investigating the association between university teachers' professional autonomy and their innovation performance. Pedagogika, 133(1), 128-148. https://doi.org/10.15823/p.2019.133.7

Griffiths, R., Chingos, M., Spies, R., \& Mulhern, C. (2014). Adopting MOOCs on Campus: A Collaborative Effort to Test MOOCs on Campuses of the University System of Maryland. Online Learning, 19(2), 1-15. https://doi.org/10.24059/olj.v19i2.523

Gütl, C., Rizzardini R. H., Chang V., \& Morales M. (2014) Attrition in MOOC: Lessons Learned from Drop-Out Students. In L. Uden, J. Sinclair, Y. H. Tao, \& D. Liberona (Eds), Learning Technology for Education in Cloud. MOOC and Big Data. LTEC 2014. Communications in Computer and Information Science, vol 446. Springer, Cham. https://doi.org/10.1007/978-3-319-10671-7_4

Israel, M. J. (2015). Effectiveness of Integrating MOOCs in Traditional Classrooms for Undergraduate Students. International Review of Research in Open and Distributed Learning, 16(5), 102-118. https://doi.org/10.19173/irrodl.v16i5.2222

Kravtsov, V. V., Savelyeva, N. N., \& Chernykh, T. V. (2015). Smeshannoe obuchenie kak otvet na vyzovy sovremennomu obrazovaniyu. [Blended learning as a response to the challenges of modern education]. Obrazovatel'nye tekhnologii $i$ obshchestvo [Educational technology and society], 4, 659-669.

Kursun, E. (2016). Does Formal Credit Work for MOOC-Like Learning Environments? International Review of Research in Open and Distributed Learning, 17(3), 75-91. https://files.eric.ed.gov/fulltext/EJ1102688.pdf

Nagaeva, I. A. (2016). Smeshannoe obuchenie v sovremennom obrazovatel'nom processe: neobhodimost' i vozmozhnosti [Blended learning in the modern educational process: necessity and opportunities]. Domestic and foreign pedagogy, 6(33), 56-67.

Pluzhnikova N. N., Korableva E. V., \& Bokova T. N. (2018). Intelligence and technology: the problem of interaction. Revista ESPACIOS, 39(38), 1-7.

Tambovkina, T. Y. (2017). Transformacii organizacionnyh form obucheniya $v$ yazykovom vuze. [Transformation of organizational forms of education in a language university]. In N.V. Yazykova, L. G. Vikulova, O. G. Lukoshus, I. V. Makarova (Eds.), Professional'noe stanovlenie uchitelya inostrannogo yazyka $\mathrm{V}$ sisteme pedagogicheskogo obrazovaniya. (Professional formation of a foreign language teacher within the system of pedagogical education) (pp. 284-288). Obshchestvo s ogranichennoj otvetstvennost'yu "Yazyki Narodov Mira" (Limited Liability Company "Languages of the Nations of the World").

Thambusamy, R. X., \& Singh P. (2021). Online assessment: how effectively do they measure student learning at the tertiary level? The European Journal of Social \& Behavioural Sciences, 30(1), 106-131. https://doi.org/10.15405/ejsbs.289

Wang, X., Hall, A. H., \& Wang, Q. (2019). Investigating the implementation of accredited massive online open courses (MOOCs) in higher education: The boon and the bane. Australasian Journal of Educational Technology, 35(3), 1-14. https://doi.org/10.14742/ajet.3896

Yang, H., \& Su, C. (2017). Learner Behaviour in a MOOC Practice-oriented Course: In Empirical Study Integrating TAM and TPB. The International Review of Research in Open and Distributed Learning, 18(5), 35-63. https://doi.org/10.19173/irrodl.v18i5.2991

You, H. (2019). Students' Perception about Learning using MOOC. International Journal of Emerging Technologies in Learning (Ijet), 14(18), 203. https://doi.org/10.3991/ijet.v14i18.10802 